Cornell University Law School Scholarship@Cornell Law: A Digital Repository

\title{
"Never Having Loved at All": An Overlooked Interest that Grounds the Abortion Right
}

Sherry F. Colb

Cornell Law School, sfc44@cornell.edu

Follow this and additional works at: http://scholarship.law.cornell.edu/facpub

Part of the Law and Society Commons

\section{Recommended Citation}

Sherry F. Colb, "'Never Having Loved at All': An Overlooked Interest that Grounds the Abortion Right," 48 Connecticut Law Review (2016)

This Article is brought to you for free and open access by the Faculty Scholarship at Scholarship@Cornell Law: A Digital Repository. It has been accepted for inclusion in Cornell Law Faculty Publications by an authorized administrator of Scholarship@Cornell Law: A Digital Repository. For more information, please contact jmp8@cornell.edu. 


\title{
CONNECTICUT \\ LAW REVIEW
}

\begin{tabular}{lll}
\hline \hline VOLUME 48 & FEBRUARY 2016 & NUMBER 3 \\
\hline \hline
\end{tabular}

Essay

\section{"Never Having Loved at All": An Overlooked Interest that Grounds the Abortion Right}

\begin{abstract}
SHERRY F. COLB
Feminist and some other abortion rights advocates typically ground the right to abortion in bodily integrity, thus conceptualizing abortion as vindicating a right to disassociate oneself from an intruder. Although valid as a matter of logic, the bodily integrity argument is libertarian and seemingly selfish. But a fundamentally associative interest also grounds the abortion right. A woman who cannot raise a child but is legally required to bear one must undergo the psychic pain of forced separation from an infant whom she is biologically programmed to love. Human mothers, like other mammalian mothers, grieve the loss of their young, as illustrated by the sad plight of dairy cows. Accordingly, the abortion right may be best understood as protecting not only an interest in bodily separation, but an interest in avoiding loss, that is, an interest in "never having loved at all."
\end{abstract}




\section{ESSAY CONTENTS}

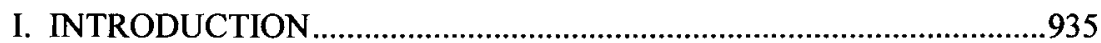

II. BODILY INTEGRITY AND OFFSPRING SELECTION ....................937

III. BEYOND THE BII AND OSI: THE INHLAA ..................................939

IV. THE GIRLS WHO WENT AWAY ..................................................941

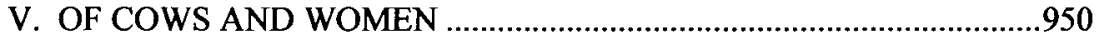

VI. APPLICATION OF THE DAIRY COW'S EXPERIENCE TO THE HUMAN RIGHT TO ABORTION ….................................956

VII. IMPLICATIONS FOR THE REGULATION OF ABORTION

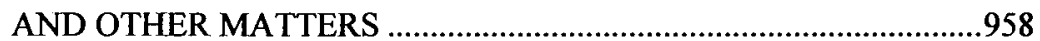

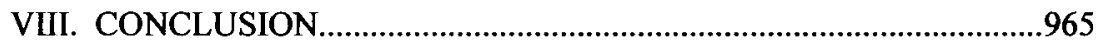

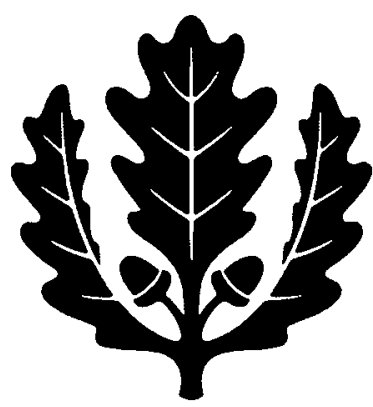




\title{
"Never Having Loved at All": An Overlooked Interest that Grounds the Abortion Right
}

\author{
SHERRY F. COLB ${ }^{*}$
}

\section{INTRODUCTION}

Defenders of a woman's right to abortion have long emphasized an interest in rejecting or repelling unwanted associations. Scholars in general and feminist scholars in particular (including me) have identified as crucial the bodily integrity invasion entailed in compelling a woman to remain pregnant against her will. ${ }^{1}$ Unlike ordinary prohibitions against acts of violence, to which pro-life activists compare the anti-abortion legislation that they seek, an abortion ban imposes upon a woman experiencing an unwanted pregnancy a months-long, physically intrusive, healthcompromising, risky, and often painful condition, followed by an

* Professor of Law and Charles Evans Hughes Scholar, Cornell Law School. The author expresses gratitude for the outstanding and painstaking research assistance of Yuliya Neverova (Cornell Law School Class of 2015) and for the very helpful comments and suggestions of the following scholars: Scott Altman, David Cruz, Michael C. Dorf, Sam Erman, Ronald Garet, Hannah Gary, Andrei Marmor, Camille Gear Rich, Stephen Rich, Daria Roithmayr, Hilary Schor, Michael Shapiro, Nomi Stolzenberg, and Abby Wood. Also, the USC Center for Law, History, and Culture (CLHC) Workshop Series, provided a fertile forum for presenting and receiving feedback on this Essay.

' See, e.g., Sherry F. COlB, Mind If I ORDER THE ChEeseburger? AND Other Questions People Ask Vegans 89 (2013) [hereinafter Questions People Ask Vegans] ("For the pregnant woman who does not want to be pregnant, there is no third option through which she can decide not to inflict injury and death on the fetus and not to undergo the enormous burden of carrying a pregnancy to term, with all of the intimate cost and risk entailed."); FRANCIS M. KAMM, CREATION AND ABORTION: A STUdy IN MORAL AND Legal PHILOSOPHy 14 (1992) ("[T]he prohibition of abortion may be a concern because it interferes with bodily autonomy and integrity (the right not to have one's body imposed upon), rather than because it limits autonomy in general."); EILEEN L. MCDONAGH, BREAKING THE ABORTION DEADLOCK: FROM CHOICE TO CONSENT 155 (1996) ("The Supreme Court in Roe $v$. Wade affirmed that women have the right of privacy to make choices about their own reproductive lives without state interference. The flaw in this perspective, however, is that it is not the state that imposes wrongful pregnancy: it is the fetus. The obvious question is why in over twenty years of reasoning about abortion rights the Court has failed to see that the primary right at stake is a woman's right to be free of the fetus's intrusion of her bodily integrity and liberty and, concomitantly, the state's obligation to set her free to the degree that it does so for others whose bodily integrity and liberty has been imposed on by private parties."); Sherry F. Colb, To Whom Do We Refer When We Speak of Obligations to "Future Generations"? Reproductive Rights and the Intergenerational Community, 77 GEO. WASH. L. REV. 1582, 1583 (2009) [hereinafter Colb, Obligations to "Future Generations"] ("[A woman's bodily integrity interest] is both weighty and directly implicated in the abortion decision."); Judith Jarvis Thomson, A Defense of Abortion, 1 PHIL. \& PUB. AFF. 47, 56 (1971) ("[Even if a fetus has a right to life, that] does not guarantee having either a right to be given the use of or a right to be allowed continued use of another's body - even if one needs it for life itself."). 
excruciating —and also risky—labor and delivery process.

The interest in bodily integrity is not, of course, the only interest that has been invoked to support the abortion right. For example, Roe v. Wade located the right in a line of cases involving decisions about privacy, sex, and procreation. ${ }^{3}$ But the later case law recognizes the interest in bodily integrity as equally important. ${ }^{4}$ And as noted, the feminist literature has tended to emphasize bodily integrity, perhaps in part because it distinguishes the interest of women from that of men in a way that the interest in not procreating fails to do.

Bodily integrity fits well with American constitutional law and culture, because it is libertarian. Conservatives, no less than liberals, express skepticism towards government regulation of the human body. Consider that in dramatizing their case against the Affordable Care Act, conservatives likened the mandate to purchase health insurance to a government mandate to purchase broccoli, tacitly but unmistakably invoking the specter of a government mandate to eat broccoli, which would have been widely regarded as an unwarranted interference with the human body. ${ }^{5}$

Yet if bodily integrity has served the abortion rights cause well in some respects, in one important respect, it has undermined the cause. The interest in bodily integrity is an interest in separation. Asserting it makes women appear selfish or callous. It opens the door to the pro-life argument that abortion pits mothers against their own babies. It forgoes what, for lack of a better term, might be called a cultural feminist argument for abortion rights.

This Essay develops just such an argument by pointing to a commonly overlooked interest that the abortion right protects - an interest in avoiding the emotional trauma of giving birth to a baby, only to have to be separated from that baby. A woman who decides she cannot raise a baby but is forced by law to bear that baby will, in effect, be forced to give her baby up for adoption. While many women willingly give up their babies for adoption, others do not, and the experience is often wrenching.

This Essay delineates the interest in "never having loved at all." It draws on examples of regimes of forced surrender. It also shows how other areas of the law tacitly recognize this interest. And it examines the

${ }^{2} 410$ U.S. 113 (1973).

${ }^{3}$ Id. at 152-53 (citing contraception cases). As explained in Part II, infra, the most precise way to describe this interest may be as an interest in "offspring selection."

${ }^{4}$ See Planned Parenthood of Se. Pa. v. Casey, 505 U.S. 833, 857 (1992) ("Roe . . may be seen ... as a rule ... of personal autonomy and bodily integrity ....").

${ }^{5}$ See Michael C. Dorf, Commerce, Death Panels, and Broccoli: Or Why the Activity/Inactivity Distinction in the Health Care Case Was Really About the Right to Bodily Integrity, $29 \mathrm{GA}$. ST. U. L. REV. 897, 901 (2013) ("[F]orced consumption of broccoli raise[s] the specter of a government that directs people's intimate decisions about the use of their bodies."). 
biological basis for attachment between mother and young that is common among mammalian mothers by describing the victimization of dairy cows who are repeatedly impregnated, only to have their just-born calves removed from them so that humans may consume their milk.

In calling attention to how the abortion right protects women's interest in attachment to their babies, rather than merely seeking to vindicate their right to detach their bodies, this Essay offers a rejoinder to the pro-life claim that their cause is truer to women's ostensibly compassionate nature. However, the thesis of this Essay is not merely strategic. The interest in "never having loved at all" is real, and it offers a powerful reason to protect the right to abortion, quite apart from its political utility.

\section{BODILY INTEGRITY AND OFFSPRING SELECTION}

Before elaborating the work that can be done by the interest in "never having loved at all," we should acknowledge that other interests can and do ground the abortion right as well. Thus, in prior work, I have explained, as other scholars have, that one can favor the abortion right in order to protect the "Bodity Integrity Interest" (or "BII") without rejecting the moral weight of the embryo or fetus. ${ }^{6}$ In other words, one can assume, for argument's sake, that an embryo or fetus is the moral equal of a newborn baby and simultaneously endorse a right to abortion, based on the BII.

Identifying a second ground for defending abortion rights, my prior work also discussed what I termed the "Offspring Selection Interest" (or "OSI") ${ }^{7}$ The OSI is an interest in determining with whom and when one will and will not procreate. Because of the OSI, people are not expected or required-even under the most demanding religious strictures-to procreate indiscriminately and at every available opportunity. People can be choosy about partners, a choosiness that reflects not only a bodily integrity interest but also the view that not all couplings resulting in offspring are desirable. We thus recognize that people legitimately reject and refuse to create some potential offspring that they could have created.

In elaborating the OSI, I have explained that the word "adultery" implies the threat of adulterating and thereby corrupting the paternal line of offspring. ${ }^{8}$ Understood in broad terms, the OSI has a very long history, one that precedes the notion that people necessarily hold an individual right to determine their reproductive destiny. In the past (and in some cultures, even today), parents and other community members (such as "matchmakers") were the ones who had the power to choose a mate for the individual. Nonetheless, there was still a recognized OSI, but historically it

\footnotetext{
${ }^{6}$ Colb, Obligations to "Future Generations," supra note 1, at 1583.

${ }^{7}$ Id.

${ }^{8} I d$. at 1586
} 
resided in the individual's family or community (which could reject proposed couplings and thereby exercise its OSI regardless of an individual's will) rather than residing in the individual herself. ${ }^{9}$ In modern thinking, we tend to recognize the OSI as an entitlement of individuals and couples - rather than of ancestors and communities.

Yet there are practices (such as genetic counseling for couples expecting a baby and abortion allowances for pregnancies involving an "impaired" fetus) that continue to reflect the notion that people are entitled to refrain from creating offspring that they have no desire to create, whether because of the identity of the potential partner, the number of children they already have, or the knowledge that the particular embryo or fetus carries a genetic anomaly.

The OSI is an interest that finds expression not exclusively (or even mainly) in the right to terminate a pregnancy, but in the right to avoid pregnancy in the first place, either by refraining from having sex (a method that, again, finds little resistance in religious doctrines) or by using natural contraceptive methods, such as the fertility awareness method (or "FAM"), ${ }^{10}$ as well as artificial contraception, such as the pill, diaphragms, and condoms. To invoke the OSI in the context of an extant pregnancy, one must reject the idea that an embryo or fetus has the same moral status as a newborn baby, because once a baby exists, it would no longer be accurate to describe an abortion as a means of avoiding the creation of offspring.

If there is no right to kill existing offspring (such as an unwanted newborn baby), which virtually no one argues there is or ought to be, ${ }^{11}$ there would correspondingly be no right to kill an embryo or fetus - as a matter of the OSI - if one shared the view that an embryo or a fetus has already become a rights-bearing individual. In contrast to the BII, then, invocation of the OSI on its own necessarily endorses a view of embryos or fetuses subject to abortion as morally entitled to less weight than a

${ }^{9}$ See id. ("Contrary to appearances, however, arranged marriage paradoxically affirms the value a community places on controlling who comes into existence.").

${ }^{10}$ See Fertility Awareness-Based Methods (FAMs), PLANNED PARENTHOOD, https://www.planned parenthood.org/learn/birth-control/fertility-awareness [http://perma.cc/66D6-WPMK] (last visited May 24, 2016) ("Fertility awareness-based methods (FAMs) are ways to track ovulation-the release of an egg - in order to prevent pregnancy. Some people call FAMs 'natural family planning.' . . FAMs work by keeping sperm out of the vagina in the days near ovulation, when a woman is most fertilemost likely to become pregnant. To prevent pregnancy, women can abstain from vaginal intercourse on their fertile days.").

${ }^{11}$ One exception is Peter Singer, who, applying a utilitarian calculus, has proposed that a baby who has a disability that will inflict tremendous suffering on the baby and his family could justly be subject to infanticide by the parents, if they prefer this option to keeping the child in the world. PETER SINGER, RETHINKING LifE AND DEATH: THE COLlaPSE OF OUR TRADITIONAL ETHICS 128-31 (1994) (discussing selective non-treatment and infanticide for the disabled). 
newborn baby and perhaps to no weight at all. ${ }^{12}$

As one example of how the OSI informs moral and legal reasoning, consider frozen embryo disputes. In such cases, a couple creates frozen embryos with the plan of implanting them and thereby creating a family. In the interim, however, the couple decides to separate or divorce, and one member of the couple decides that he (or she) no longer wishes to have the embryos (or pre-embryos) become children. In such cases, the member of the couple who opposes implantation is asserting his right not to procreate, and that right is not directly tied to an interest in maintaining bodily integrity, especially if it is the man who opposes implantation. When the opponent of implantation prevails, at least one reason for that victory is the OSI that allows an individual to decide to avoid altogether the association necessarily involved in having a child.

In one well-known such case that I discuss at greater length in Part VI below, the Tennessee high court ultimately ruled in favor of the opponent of implantation, Junior Davis, agreeing that his right not to procreate trumped his ex-wife's interest in becoming a genetic parent, given that her plan was to donate the resulting embryos to another couple. ${ }^{13}$ Junior Davis's OSI was at least part of what explained his right not to be compelled to be a biological father to a child whose existence he opposed, a right necessarily premised on the view that an embryo is not itself already a child (with a corresponding right not to be killed). ${ }^{14}$

\section{BEYOND THE BII AND OSI: THE INHLAA}

I have recently come to think that the foregoing typology of interests that underlie women's need for a right to abortion is incomplete. There remains an interest that women have in terminating a pregnancy, and that interest goes unexpressed by the Bodily Integrity Interest and the Offspring Selection Interest alone. The interest has more to do with attachment and love ${ }^{15}$ than it does with a freedom to repel unwanted associations, so it is quite different in kind from both the BII and the OSI. For ease of reference,

\footnotetext{
${ }^{12}$ Sherry F. Colb \& Michael C. Dorf, Beating Hearts: Abortion and animal Rights (2016).

${ }^{13}$ Davis v. Davis, 842 S.W.2d 588, 604 (Tenn. 1992), reh'g granted in part, No. 34, 1992 WL. 341632 (Tenn. Nov. 23, 1992).

${ }^{14} \mathrm{Id}$. at 594 .

${ }^{15}$ For a fascinating discussion of a different love interest driving the desire for an abortion - the love of other family members whose needs will be undermined by the addition of a baby to the family-see Julia E. Hanigsberg, Homologizing Pregnancy and Motherhood: A Consideration of Abortion, 94 MICH. L. REv. 371, 402 (1995) ("One story the group shared contained the following statement that reflects concems based in the intersecting relationships in which the woman in question found herself: 'I am a junior in college and am putting myself through because my father has been unemployed and my mother barely makes enough to support the rest of the family. I have promised to help put my brother through when I graduate next year and it's his turn. . . . There is no way I could continue this pregnancy because of my responsibilities to my family. "').
} 
I will refer to this new interest as the "Interest in Never Having Loved at All" ("INHLAA").

Alfred Lord Tennyson said, in In Memoriam A.H.H., "Tis better to have loved and lost [t]han never to have loved at all."16 This statement is, in one respect, quite insightful. It expresses the idea that even though it can be extremely painful to lose a loved one, a life may be better lived if it includes the vulnerability that comes with truly loving another, even though such love-if reciprocated-almost always leads to someone experiencing tremendous pain and grief when the other loved one is no longer in the world or no longer in one's life. Such love may be of the romantic sort or it may be the love that one has for a dear friend, a relative, a child, or a companion animal. ${ }^{17}$

Yet the idea that it is better to have loved and lost has its limits. People who subscribe in their own lives to this idea generally choose to enter into their cherished relationships. In the case of romantic love, two people might fall in love and decide to commit to each other for life, until death do they part. When one partner dies, the other-grief-stricken and perhaps even beyond consolation - may still not regret having loved the one who is lost.

The feelings of the bereaved would probably be very different, however, if some third party deliberately brought about an intense relationship of love between the two people with the advance knowledge that the parties to the relationship would soon be deliberately torn from each other's embrace. In such a case, the creation of the relationship itself - with the knowledge that it would not last and that its loss would leave terrible pain in its wake-would be an act of cruelty, of knowingly inflicting trauma on the unsuspecting without any compensating benefit. It is difficult to imagine, in these circumstances, that the victims of this third party would praise the third party who knowingly brought about this tremendous suffering for giving the parties the opportunity to have "loved and lost."

It is the interest in avoiding this injury that I am calling the INHLAA, the interest in never having loved at all, when the particular love provides little joy and overwhelming grief. But when, the reader may be wondering, does anyone deliberately bring about relationships destined to end prematurely in excruciating sorrow? When third parties manipulate the

\footnotetext{
${ }^{16}$ Alfred Lord Tennyson, In Memoriam A.H.H. 37 (Bankside Press 1900) (1849).

${ }^{17}$ The book, Let's Take the Long Woy Home, is a memoir of such a friendship, and it is plain that the author, Gail Caldwell, treasured the time she had with her best friend and would not have had it any other way, despite the enormous grief she experienced at the unexpected death of her beloved friend, author Caroline Knapp. Gall, CALDWELl, LeT'S TAKE THE LONG WAY HOME: A MEMOIR OF FRIENDSHIP 196 (2010) (noting in an interview that "[t]he most meaningful passages for [the author] were also, not surprisingly, the most difficult, or at least bittersweet, to write").
} 
reproductive lives of others.

\section{THE GIRLS WHO WENT AWAY}

In The Girls Who Went Away The Hidden History of Women Who Surrendered Children for Aaption in the Decades Before Roe v Wade, Ann Fessler tells the stories of young women who became pregnant in the years before Roe $v$. Wade legalized abortion in the United States. ${ }^{18}$ At the time, an out-of-wedlock pregnancy would have been a source of great shame to a girl (or woman) and to her family. Thus, many families sent their pregnant daughters "away" to places where they could continue their pregnancies without an audience and ultimately give birth and have their babies taken from them and given, for adoption, to intact families. ${ }^{19}$ Fessler recounts that many of the young mothers fell in love with their babies and did not want to give them up for adoption. ${ }^{20}$ Yet keeping the child was not an option for these girls, and many were either tricked, pressured, or forced into surrendering whatever rights they had to keep their babies. ${ }^{21}$

Girls in this situation suffered great trauma from which some never fully recovered. ${ }^{22}$ Yet Fessler's powerful book is aimed not primarily at criticizing the girls' families or the surrounding culture for pressuring the girls into surrendering their infants at birth. Instead, the message of the book - to the extent that there is one-is that an important source of the girls' pain was the prohibition against abortion, the law that compelled

\footnotetext{
${ }^{18}$ AnN Fessler, The girls Who Went AWay: THE HidDEN History of Women Who SURRENDERED CHILDREN FOR ADOPTION IN THE DECADES BEFORE ROE $V$. WADE (2006).

${ }^{19} \mathrm{Id}$. at 8 ("Though sexual norms were changing among the young, the shame associated with single pregnancy remained. The social stigma of being an 'unwed mother' was so great that many families - especially middle-class families-felt it was simply unthinkable to have a daughter keep an 'illegitimate' child. These women either married quickly or were sent away before their pregnancy could be detected by others in the community. Between 1945 and 1973, one and a half million babies were relinquished for nonfamily or unrelated adoptions.").

${ }^{20}$ Id. at 181 ("After the birth, when the reality of motherhood had sunk in, many of these women were desperate to formulate a plan other than relinquishment. But there was no system of advocacy for a woman who knew she wanted to mother from the beginning, nor any effective recourse for those who came to that realization after their babies were born.").

${ }^{21}$ Id. ("Many women were presented with papers in the hospital while they were still recovering from childbirth and were authoritatively instructed to sign. Some did not even understand what they were signing. Often these papers gave temporary or joint custody to the adoption agency, and once the child was in the agency's care the mother had a more difficult time, both legally and emotionally, halting the process. Though each state did have a set period of time during which the mother could revoke consent, as they still do, many women who announced that they had changed their minds or who asked about having more time to decide were not informed of their legal rights but rather were told it was too late. The only staff person most of them had to turn to was the caseworker, and most of these were strong advocates for surrendering.").

${ }^{22}$ Id. at 207 ("Surrendering a child for adoption has been described by many of the women [Fessler] interviewed as the event that defined their identity and therefore influenced every major decision they made thereafter.").
} 
them to take their pregnancies to term. ${ }^{23}$

In one sense, this causal attribution might sound like a non-sequitur. If the girls suffered so terribly because they were not permitted to keep their beloved infants, wouldn't the obvious solution be to permit them to keep their babies, rather than to allow them to terminate their pregnancies before the babies had even become babies? For some of the girls, the answer might well have been "yes."

These girls could have been opposed to abortion on religious or moral grounds, or might have felt love for their unborn life from the moment they learned they were pregnant, as many women do. For them, the best outcome would indeed have been a supportive opportunity for them to remain with their children instead of having to surrender them to other people who wanted a child. ${ }^{24}$

${ }^{23}$ See id. at 53 ("I've experienced both [adoption and abortion] and I'd have an abortion any day of the week before I would ever have another adoption-or lose a kid in the woods, which is basically what it is. You know your child is out there somewhere, you just don't know where. It's bad enough as a mother to know he might need you, but to complicate that they make a law that says even if he does need you we're not going to tell him where you are.").

${ }^{24}$ See id. at 10 ("Another prevailing myth is that these women were all eager to surrender their child and be free of their problem."). For the poignant story of a couple that was greatly wounded by a pregnancy that they did not intend (because a fertility clinic implanted the wrong embryo inside the woman), see Carolyn Savage \& Sean Savage, InConceivable: A MEdiCal Mistake, the Baby WE COULDN'T KEEP, AND OUR CHOICE TO DELIVER THE ULTIMATE GIFT 1 (2010) ('That absent child is always with you, a loss you feel some days as yearning and other days in a gasp of pain. My husband Sean and I still grieve the son we lost, despite the unusual way he left us. Or rather, we still grieve him and the circumstances that forced us to give away a baby we thought of as our own."). In the case of the author of this book, abortion was not an option, because she was a religious Catholic. Id. at 22-23 ("After all, we were a strong Catholic family, and our choices about how to spend our time and raise our children had always been consistent with our religious beliefs. In addition, I had worked my entire career in Catholic schools, and Sean was raised in a devout Catholic family. Our boys attended a Catholic school, and nearly all of our friends were people we knew from church or school. Considering how we lived our lives, we couldn't lightly dismiss church doctrine on the subject."); see also id. at 1112 ("This was a human life, and we would protect it."). The only way out of the situation, in this couple's case, would have been for the fertility clinic not to have implanted in the woman an embryo that could never be hers in the first place. We can see here the woman's (and her husband's) Interest in Never Having Loved at All (INHLAA), expressed eloquently in this book detailing the couple's emotional struggle with the intense bond that the woman (and her husband) developed with the baby growing inside Carolyn, even as they anticipated having to say goodbye at the end. For a similar story of suffering resulting from the involuntarily imposed love and bonding resulting from the birth of an unplanned baby, see Matthew McKnight, The Ohio Sperm-Bank Controversy: A New Case for Reparations?, NEW YORKER (Oct. 14, 2014), http://www.newyorker.com/news/news-desk/ohio-spermbank-controversy-new-case-reparations [http://perma.cc/EA33-5W4E] (depicting the story of the lesbian couple who recently sued a sperm bank for implanting the wrong embryo, resulting in an interracial baby whom the couple wants to keep and loves very much but who will generate unwanted challenges in the less-than-tolerant setting in which the couple is bringing up the child). What is fascinating about this story is that the lawsuit exposes two seemingly paradoxical feelings that occur simultaneously - the feeling of regret for having come to be in a relationship that generates distress, and the feeling of love and attachment that makes giving up the child for adoption unthinkable. An appreciation for the INHLAA helps us to resolve the seeming paradox and understand that one can 
Other girls, however, would likely have terminated their pregnancies if they had had the opportunity to do so, especially if they were not planning to keep their babies. ${ }^{25}$ I suspect, moreover, that an even greater number of the girls would have aborted if they had learned from friends who had given birth and had their children taken away how traumatic such an experience could be. The girls' knowledge that they would likely come to feel attached to their babies-but would nonetheless have to give them up (for whatever reason) - would make an abortion very attractive, for this option would help avoid both the bonding and the loss that could predictably occur if they took their pregnancies to term. ${ }^{26}$

There is undoubtedly an irony in what I am saying. I am suggesting that to avoid the pain of losing a child to adoption, a pregnant woman could understandably and legitimately choose instead to end the life of her unborn child intentionally, through abortion. This might, at least at first glance, sound a bit like the abusive husband who has engaged in domestic violence against his wife and then kills her at the point that she decides that she will leave him. ${ }^{27}$ "If I can't have you, then nobody can" is the chilling phrase associated with spousal murder in these situations. ${ }^{28}$

coherently hold both of these feelings at the same time and therefore sue because of the creation of a child whom one now adores and with whom one would never consider parting.

${ }^{25}$ Some women did have the opportunity to obtain a legal abortion abroad, or an illegal domestic abortion. See FESSLER, supra note 18, at 110 ("A common belief at the time was that girls from affluent homes routinely obtained abortions out of the country or through doctors in their communities who charged a hefty sum. Those who desired and could afford an illegal abortion could often find one.").

${ }^{26}$ See supra note 23 and accompanying text.

${ }^{27}$ The most dangerous and potentially lethal period for the victim of domestic violence is the period during which she attempts to exit the relationship with her batterer. See, e.g., Myrna S. Raeder, The Admissibility of Prior Acts of Domestic Violence: Simpson and Beyond, 69 S. CAL. L. REV. 1463, 1472 (1996) ("Although one might wonder logically how control is gained by destroying the very person being controlled, the answer is often keyed into another well-known domestic violence statistic not told to jurors - that women are in the most danger of substantial injury or death when they separate from their mates."); see also id. (citing DONALD G. DUTTON \& SUSAN K. GOLANT, THE BATTERER: A PSYCHOLOGICAL PROFILE 15 (1995) for a study that found that " $45 \%$ of femicides (murders of women) were generated by the man's rage over the actual or impending estrangement from his partner."). Raeder argues that prior domestic violence evidence demonstrates the defendant's need to exercise control over his wife and that homicide at exit becomes the final exercise of the otherwise-lost control. Id. at 1471 ("The motive for domestic murder is sometimes explained as the hostility which the defendant has borne against his wife. Yet this does not convey what is at the root of many spousal femicides. The Simpson prosecution came closest to the true cause when it argued that the many different types of abusive acts 'were all committed with the same intent and purpose-to control [the] victim's life. ... When it appeared to him that she was escaping that control he committed murder as the final act of control." (emphasis added)).

${ }^{28}$ Raeder, supra note 27 , at 1502 ("The most intellectually honest justification for Linkenauger's reasoning is that the prior domestic violence evidence is being used to prove specific rather than general propensity. If he used bad acts to control her before, it is more probable that he murdered her as the final act of control to ensure that she would not escape his authority. Ironically, the refrain "If I can't have her nobody can' is spoken all too frequently by wife killers to be truly distinctive. At heart, the signature depends on the relationship context."). 
Although batterers do in fact appear to experience such sentiments toward the objects of their romantic feelings, this is not a sentiment that I would either endorse as legitimate or attribute to a woman who wishes to terminate her pregnancy. A woman in this situation is not typically enraged at her embryo or fetus. And-unlike the battering spouse-she does not want this embryo or fetus to stay with her.

So how can I claim that killing the embryo or fetus protects the pregnant woman from the "love and loss" that accompany surrender of a child to adoption? Here, as in the case of the OSI-Offspring Selection Interest - my claim rests on the assumption that for at least some portion of her pregnancy-perhaps that portion that precedes the fetus becoming sentient and thus capable of sensations or emotions-the embryo or fetus is not yet "someone" but remains instead "something," a bundle of growing cells that will, if permitted, become someone at a later point. To the extent that one believes that a zygote at conception is the moral equivalent of a newborn baby, one will reject the argument that I make here, just as one would properly reject the prerogative of a woman to kill her newborn baby to protect herself from emotional injury. ${ }^{29}$

\footnotetext{
${ }^{29}$ One could still rely on the BII as a basis for protecting the right to abortion, even if one regarded an embryo or fetus as the moral equivalent of a newborn baby. However, reliance on the BII on these terms would necessarily mean that if it were possible to provide an artificial womb and to terminate a woman's pregnancy without killing the fetus (and without physically harming the woman any more than she would be harmed by an abortion), this possibility would take away the woman's right to kill the fetus. In other words, relying on the Bodily Integrity Interest does not carry with it the right to actually kill the embryo or fetus, except as it is a necessary condition of restoring the woman's bodily integrity. If, on the other hand, one believes-as I do-that an embryo or fetus lacks the moral weight of a newborn baby (and perhaps lacks all moral weight), then the OSI could still ground a right to destroy the embryo or fetus, even in the presence of an artificial womb. The question of whether the INHLAA could ground a similar right to destroy the embryo or fetus would be a difficult one because the woman who resorted to an artificial womb would have avoided birth (and thus the intense bonding that would make giving up the baby to adoption at birth such a tremendous loss), but she might have begun to feel a bond from the pregnancy itself, and the knowledge that the fetus would continue to develop in the artificial womb could perhaps induce feelings of greater bonding that the woman might legitimately wish to avoid. Such a case would be very much like the case of the man who opposes the implantation of an embryo made with his sperm, on the ground that he will inevitably feel a pull toward a child created from his DNA, and that he would suffer loss from knowing that the child is elsewhere in the world. Again, the assertion of this Interest in Never Having Loved at All necessarily assumes-for a man and in the case of the artificial womb-that the embryo is not a rights-bearing entity with an interest in continued life, and the interest in such cases also does not carry the additional weight that goes with the intense, singular, and non-contingent bonding that accompanies childbirth. I am aware of the potential charge of essentialism here, but just as some feelings (such as euphoria and depression) can reliably be induced in all animals, including humans, there is little reason to doubt that feelings of bonding and attachment are similarly subject to the same kind of reliable induction in pregnancy followed by birth. See, e.g., Bret Stetka, Can Fear Be Erased?, SCI. AM. (Dec. 4, 2014), http://www.scientificamerican.com/article/can-fear-be-erased/ [https://perma.cc/CL3S-BL87] ("The hormone was oxytocin, often called our 'love hormone' due to its crucial role in mother-child relationships, social bonding, and intimacy (levels soar during sex). But it also seems to have a significant antianxiety effect. Give oxytocin to people with certain anxiety disorders, and activity in the amygdala - the primary fear center in human and other mammalian brains, two almond-shaped bits of
} 
It would not be legitimate for one rights-holder to kill another rightsholder as a means of avoiding emotional distress, any more than it would be legitimate for a man or a woman to kill a one-year-old because he or she strongly prefers not to be the parent of a child at this time. Once the zygote, embryo, or fetus attains the status of "someone," only the BII-the Bodily Integrity Interest - can provide an account of justifiable killing, because it rests squarely on the reality that the woman who remains pregnant is forced to serve as a physical incubator to her child, and such a burden - even for the sake of keeping another alive - is arguably too great to impose without consent.

However, if we do accept the proposition that a fetus is less than "someone" prior to becoming sentient, then the right to avoid "love and loss" makes a great deal more sense and fills a gap in the picture of those interests legitimately furthered by the right to abortion. When a woman carries a pregnancy to term and endures labor and delivery - by contrast to when she terminates her pregnancy at an early stage (and perhaps even at a later stage) - she is likely to experience a sense of tremendous attachment to the infant to whom she has given birth. There are a number of reasons for this, but one is biological: mammals produce hormones during labor, including oxytocin, which-like a drug that activates our neural networks -induce feelings of love and bonding in both the woman and her young infant. ${ }^{30}$

brain tissue sitting deep beneath our temples-falls."). For further discussion of oxytocin, see infra note 30 and accompanying text

${ }^{30}$ See Natalie Angier, The Biology Behind the Milk of Human Kindness, N.Y. TiMES (Nov. 23, 2009), http://www.nytimes.com/2009/11/24/science/24angier.html ("Scientists have long known that the hormone [oxytocin] plays essential physiological roles during birth and lactation, and animal studies have shown that oxytocin can influence behavior too, prompting voles to cuddle up with their mates, for example, or to clean and comfort their pups. Now a raft of new research in humans suggests that oxytocin underlies the twin emotional pillars of civilized life, our capacity to feel empathy and trust."); see also Keith M. Kendrick, Oxytocin, Motherhood and Bonding, 85 EXPERIMENTAL PHYSIOLOGY 111s, 111s (2000) (" $[\mathrm{In}] 1986$. . . detailed evidence was produced in sheep that brain oxytocin levels are elevated by vagino-cervical stimulation occurring at the time of birth." (citation omitted)); Gretchen Reynolds, The 'Love Hormone' as Sports Enhancer, N.Y. TIMES (Nov. 21, 2012), http://well.blogs.nytimes.com/2012/11/21/the-love-hormone-as-sports-enhancer/ ("New mothers are awash in oxytocin (which is involved in the labor process), and it is believed that the hormone promotes bonding between mother and infant."). Some women may, of course, feel no such attachment to their newborn babies, a fact that might either make it easier to give up their children for adoption or make it difficult to carry out the obligations of parenthood as planned. I mean in no way to either deny, minimize, or disrespect the circumstances of women facing this alternative-and potentially very challenging - situation; I mean only to suggest that they represent exceptions rather than the rule, and it is therefore crucial to provide an option for the more common scenario in which a woman can reliably be expected to fall in love with her new infant at birth. Women who fall outside this category, moreover, still have every right to rely on the Bodily Integrity Interest (BII) as a foundation for their right to terminate their pregnancies at an early stage, even if we assume that they can predict that separating from a biological child at birth will not harm them in the way that it would harm most women in the situation. 
The law of adoption implicitly acknowledges the power of these feelings by giving a woman (who has agreed to surrender her child for adoption) some period of time after she gives birth during which she has the right to change her mind and to decide to keep her baby after all. ${ }^{31}$ This waiting period tacitly recognizes that even if a woman has felt relatively disconnected from her pregnancy and from the developing baby she would be delivering at the end, the birthing process itself could change her perspective dramatically to make the prospect of giving up her baby legitimately unthinkable to her. ${ }^{32}$ In an ideal world, it might be that the

${ }^{31}$ Many states have enacted statutes to provide for the revocation of consent. See CHILDREN'S Bureau, U.S. DeP'T of Health \& Human Servs., Consent to Adoption 5 (2013), https://www.childwelfare.gov/systemwide/laws policies/statutes/consent.pdf [https://perma.cc/4X4CKZQG] ("In most States, the law provides that consent may be revoked prior to the entry of the final adoption decree under specific circumstances or within specified time limits."). The time periods and the reasons for revocation of consent vary from state to state. See, e.g., id. at 6 ("The birth parent is allowed to withdraw consent within a specified period of time, after which consent is irrevocable unless there is evidence of fraud or duress."); id. at $6 \mathrm{n} .18$ ("California (2 years for an Indian child), Iowa (96 hours), Maine ( 3 days), Minnesota (10 days), North Carolina (7 days), Oklahoma (30 days), Pennsylvania (30 days), Tennessee (10 days), Texas (10 days), Vermont (21 days), and Virginia (15 days)."). State law treatment of gestational surrogacy-where the pregnant woman is not a genetic parent of the baby-varies. See, e.g., Tamar Lewin, Surrogates and Couples Face a Maze of Laws, State by State, N.Y. TIMES (Sept. 17, 2014), http://www.nytimes.com/2014/09/18/us/surrogates-andcouples-face-a-maze-of-laws-state-by-state.html ("While surrogacy is far more accepted in the United States than in most countries, and increasing rapidly (more than 2,000 babies will be born through it here this year), it remains, like abortion, a polarizing and charged issue. There is nothing resembling a national consensus on how to handle it and no federal law, leaving the states free to do as they wish."). States which enforce surrogate contracts have perhaps failed to fully take into account the reality of bonding that occurs regardless of how-and with whose DNA-the baby was originally conceived. See, e.g., Johnson v. Calvert, 851 P.2d 776, 778, 782 (Cal. 1993) (en banc) (relying on the Uniform Parentage Act of 1975 in determining that a genetic mother is presumptively as much a "natural mother" as a birth mother and accordingly allowing the pre-conception intentions of the parties - to have the child raised by the genetic parents after being born of the gestational surrogate - to break the tie in favor of the genetic mother, a decision in which the court gave virtually no attention to the intense bonding that would have occurred during labor and delivery). Even after having taken the gestational surrogate's attachment interests into account, a court might ultimately still find for the genetic parents in a struggle between the two sides, but courts do seem to evidence a troubling tendency to overvalue genetic connection and consequently to undervalue or ignore the interests of the woman who has carried a pregnancy to term but who has no direct genetic link to the baby. Cf. Sherry F. Colb, Words That Deny, Devalue, and Punish: Judicial Responses to Fetus-Envy?, 72 B.U. L. REV. 101, 118-19 (1992) ('CDemonstrating' that life begins at conception, however, does have important implications for the question of the respective roles of males and females in procreation. When the court describes an embryo as a child, it implies that genetic contribution is biologically sufficient for procreation. In the court's reconstruction of nature, pregnancy and childbirth —of which only women are capable-are not essential to reproduction, just as in Michael $H$., that activity which women tend to do-nurturing-was not essential to the definition of constitutionally protected fatherhood.").

${ }^{32}$ One option that might provide a desirable alternative to abortion for some pregnant women is open adoption. In open adoption, a mother can maintain some level of relationship with her birth-child, notwithstanding the parental role of the adopting parents. Women who find the prospect of an open adoption attractive might decide to take a pregnancy to term when they would otherwise have preferred to terminate. See, e.g., BARBARA MELosh, STRANGERS AND KIN: THE AMERICAN WAy OF ADOPTION 281-82 (2002) (addressing some of the risks of open adoption while highlighting the benefits of this 
solution to such bonding would be to ensure that every woman who wishes to keep her newborn has the means and support to be able to do so. ${ }^{33}$ But the law and our social understandings must in the meantime address and reflect reality as it exists and as it confronts women now, rather than an idealized version of reality that might someday take its place.

For a woman who cannot keep her baby, then, the option of giving up the child for adoption does not always represent the "win/win" that it is said to be by abortion opponents. ${ }^{34}$ The opponents of abortion argue that if a pregnant woman is not in a position to keep her baby, for whatever reason, she does not have to have an abortion, because there are plenty of people who would be willing and even eager to adopt her child and raise

option that appeals to notions resembling those to which abortion appeals). Yet for many women, an open adoption will not be an adequate substitute for the relationship entailed in actual motherhood. Indeed, in some cases, it might be even harder to have an ongoing, non-parental relationship with a baby than it would be to cut off contact altogether. Either way, there will be women who wish to avoid the bonding that happens at birth to children whom they will be unable to keep, whether adoption means complete separation or whether it allows for some intermittent contact to occur. The possibility of open adoption accordingly leaves in place the important interest of pregnant women who will not be able to parent their babies in never having loved at all.

${ }^{33}$ To its credit, the pro-life group Feminists for Life (FFL) has advocated not only for legal prohibitions against abortion but also for the rights of women with small children to accommodations on college campuses. See Pregnancy Assistance Fund, FEMINISTS FOR LIFE, http://www.feministsforli fe.org/major-victory-for-pregnant-and-parenting-students/ [https://perma.cc/4GBF-FSVY] (last visited Sept. 29, 2015) ("Feminists for Life celebrates the establishment of the Pregnancy Assistance Funds for Pregnant and Parenting Students. The first federal grants of their kind-inspired by Feminists for Life's work on college campuses to develop resources for this underserved population-will be distributed this fall to establish, operate, or maintain pregnant and parenting student services."). Such advocacy empowers women who might wish to keep their babies to be able to do so while continuing to pursue an education in an environment that is currently less than ideal for new parents. The right to abortion, however, like constitutional doctrine more generally, is properly premised on the reality of what the world offers in its current state, namely, circumstances that often make it virtually impossible for many women to take on a new parental obligation at all or, at least, without seriously compromising her obligations to others in her life and to herself. By analogy, the U.S. Supreme Court held in Planned Parenthood $v$. Casey that women must not, as a matter of constitutional right, be forced to notify their spouses of a planned abortion as a prerequisite to termination. 505 U.S. 833, 892-94 (1992). It premised this holding largely on the reality that a significant number of women seeking an abortion are presently in marriages that include domestic violence, a state of affairs that would effectively pose a substantial obstacle to those women who wish to terminate a pregnancy but who fear violent retribution. $I d$. at 892-93 ("This information and the District Court's findings reinforce what common sense would suggest. In well-functioning marriages, spouses discuss important intimate decisions such as whether to bear a child. But there are millions of women in this country who are the victims of regular physical and psychological abuse at the hands of their husbands. Should these women become pregnant, they may have very good reasons for not wishing to inform their husbands of their decision to obtain an abortion."). In an ideal world, there would be no domestic violence and this argument for the right to abortion would disappear. Law, however, should address itself to reality in the world in which we live, not in a hypothetical world in which domestic violence (and, by analogy, the anticipated inability to keep and take care of a child to whom one would give birth) has disappeared as an issue.

${ }^{34}$ See RoBert D. GOLDSTEIN, Mother-LOVE AND ABORTION: A LEGAL INTERPRETATION 63-68 (1988) (presenting another very interesting and related approach to adoption's inadequacy as a substitute for abortion for pregnant women who cannot keep their babies). 
him or her as their own. ${ }^{35}$ Yet the woman who surrenders her child to adoption - particularly if she does not really feel she has the option of keeping the baby - may suffer terrible psychological distress and may have preferred to have "never loved at all" by having an abortion at a point in the pregnancy before bonding occurred, before there was "someone" in the world to whom she had become a mother. ${ }^{36}$

Putting these three interests together, then, a woman is entitled to

${ }^{35}$ See, e.g., RIGHT TO LIFE OF MICH., LIFE NOTES (2015), http://media.rtl.org/pdf/adoption.pdf [https://perma.cc/WWJ5-XQ6A] ("For the pregnant woman who is not ready or equipped to be a parent, adoption provides a positive life-giving solution to a difficult situation. For those who otherwise may not be able to have children, adoption can bring unimaginable joy. And for children, adoption can provide care they may not have otherwise received. More importantly, it may have saved them from being aborted."); see also FESSLER, supra note 18, at 9 ("The girls who went away were told by family members, social-service agencies, and clergy that relinquishing their child for adoption was the only acceptable option. It would preserve their reputation and save both mother and child from a lifetime of shame. Often it was clear to everyone, except the expectant mother, that adoption was the answer.").

${ }^{36}$ Not all women experience bonding. See Ruta Nonacs, Postpartum Depression and Bonding Difficulties: Different but Interrelated Problems, MASS. GEN. HOSP. CTR. FOR WOMEN's MENTAL HEALTH (Dec. 18, 2013), https://womensmentalhealth.org/posts/postpartum-depression-bondingdifficulties-separate-interrelated-problems [https://perma.cc/6W45-SY6S] ("However, it must be recognized that poor bonding is not universal among women with postpartum depression and that women who are not depressed may also experience bonding difficulties."); see also supra note 30 . In extreme cases, a woman is so disconnected from her baby that she may-in the throes of a post-partum psychosis, for example- be willing to commit infanticide. It is for such extreme cases that a number of states have passed "safe haven" laws permitting mothers to drop off their babies anonymously and without consequence. See Chldren's Bureau, U.S. DEP'T. OF HEalth \& Human SERvs., INFANT SAFE HAVEN LAWS 1 (2013), https://www.childwelfare.gov/pubPDFs/safehaven.pdf [https://perma.cc/ UBA5-G5H2] (providing a comprehensive state-by-state survey on the topic); see also, e.g., N.Y. PENAL LAW $\$ 260.00(2)$ (McKinney Supp. 2014) ("A person is not guilty of [child abandonment] when ... (b) the child is left . . in a suitable location and the person who leaves the child promptly notifies an appropriate person of the child's location; and (c) the child is not more than thirty days old."); id. $\$ 260.10$ (3) (citing this as a defense to endangering the welfare of a child). Historically, infanticide was more common than it currently is. See Michelle Oberman, Understanding Infanticide in Context: Mothers Who Kill, 1870-1930 and Today, 92 J. CRIM. L. \& CRIMINOLOGY 707, 707 (2002) ("Infanticide in our present society seems to be an anachronism, given our relative wealth and the widespread options for women seeking to avoid pregnancy or parenting."). Whatever its prevalence, however, the practice may say more about the crushing demands and stresses experienced by women and families having little or no access to birth control than it does about an absence of maternal bonding. See Hanigsberg, supra note 15 and accompanying text (proposing that women who terminate their pregnancies may do so out of love for the other family members to whom they have familial obligations); see also TONI MORRISON, BELOVED (1987) (depicting an enslaved woman who kills her daughter out of love for that daughter, in an effort to protect the latter from being recaptured to a life of slavery). Furthermore, the fact that maternal bonding is not universal does not take away from its overwhelming power when it does occur, which is in the vast majority of cases. See Katherine Harmon, Birth of a Bond: Illustrating a Year of Mother and Baby Development, SCI. AM. (May 8, 2010), http://www.scientificamerican.com/article/illustration-pregnancy-bond [https://perma.cc/YZD3-ZM SG] ("After birth, certain biochemical compounds are at work in both mother and child to sustain and accentuate the bond between the two. Hormones, such as oxytocin, surge in mothers after labor and during breast-feeding, promoting social and emotional bonding with the infant. And in babies, just being touched spurs the release of the same compound, helping them, in turn, bond with their moms and other care takers."). 
terminate a pregnancy because: (a) she has a Bodily Integrity Interest (the BII) in reclaiming her internal physiology from capture by an unwanted organism that, however blameless, acts as a parasite on her body while she is pregnant; (b) she has an Offspring Selection Interest (the OSI) in preventing herself from becoming a parent to a child she does not desire to have (an interest that also drives her entitlement to use birth control and that men also have); and (c) she has an emotional Interest in Never Having Loved at All (the INHLAA), an interest in protecting herself from becoming attached and bonded to someone with whom she will be forced, by third parties or by circumstances beyond her control, to surrender and mourn.

What sets the INHLAA apart from the other interests is that it fully recognizes and takes account of the love that a mother naturally (in most cases) feels for the baby to whom she has given birth. The other two interests focus instead on the undesired imposition and burden of having to gestate and labor against one's will, or of having to be a parent to someone whom one does not wish to parent. ${ }^{37}$ Underlying these interests is a negative reaction to the prospect of having the embryo or fetus in one's body, or of having the child in one's life or in the world. The experience at issue is one of wanting to be free of an undesired connection or association. $^{38}$

By contrast, the INHLAA is fundamentally about desperately wanting someone whom one cannot have and about not having to endure the pain of such a loss. The Bodily Integrity Interest is, of course, relevant to the INHLAA, because one becomes bonded to the baby precisely because one has (hypothetically against one's will) carried the baby inside one's body and delivered him or her. But the interest is not primarily focused on the period of gestation; instead it emphasizes the consequences of giving birth for the woman who does not intend to keep her child. The injury to the woman, on this account, is the trauma of having to separate from the baby she has birthed. It is the anticipated longing for connection-and not the desire for disconnection - that animates the INHLAA. ${ }^{39}$

\footnotetext{
${ }^{37}$ See Colb, Obligations to "Future Generations", supra note 1, at 1595.

${ }^{38}$ See id. ("[A] person has an interest in avoiding the creation of unwanted offspring.").

${ }^{39}$ It is worth emphasizing here that sensible laws implementing the INHLAA allocate to the woman herself the decision whether to avail herself of protection for her INHLAA. I certainly do not mean to suggest that women should be forcibly protected by law-through compelled abortion, for example-when they would prefer to bear their children and surrender them for adoption, notwithstanding the suffering involved. Likewise, if a woman acts as a gestational surrogate for another couple and decides, once she has given birth, that she can part with her newborn infant (after a period during which she may make this decision), then I would not foreclose her ability to make the choice. In short, I am arguing for the woman to have the opportunity to avoid the tremendous suffering entailed in surrendering a baby at birth-either by terminating her pregnancy in anticipation of the loss or by deciding to keep a newborn she had previously agreed to give up for adoption-but the right to assert this interest belongs to her, and it is accordingly her right to make a different choice, as best suits her
} 


\section{OF COWS AND WOMEN}

To better understand the plight of women suffering a violation of their INHLAA, consider the life of a dairy cow (or sheep, goat, or any other mammal whom humans use to make dairy products). Most people know that mammals-so named for their mammary glands-create milk inside of their bodies as a means of feeding their young. ${ }^{40}$ Through breastfeeding, a female mammal is able to use her own body to supply her baby with food.

A female mammal's body-whether human or nonhuman-thus begins producing milk as a biological response to the hormonal changes in her body that accompany pregnancy and childbirth. ${ }^{41} \mathrm{~A}$ mammal, in other words, produces milk when she has been pregnant and has given birth.

Most of us who are feminist do not think of women and other mammals in the same category. This is in large part because, as Carol Adams has explained, patriarchal norms have denigrated the value of women, and speciesist norms (norms that ask us to regard humans as the only inherently valuable sentient beings inhabiting the earth) have denigrated the status of nonhuman animals; especially those animals (such as chickens, cows, pigs, and goats) who are bred and exploited on farms to make food for humans. ${ }^{42}$ To raise the status of women relative to men,

individual situation and her own reactions to pregnancy and birth. By contrast, anti-abortion arguments about protecting women from the loss occasioned by abortion itself seek to take the choice away from the woman involved and thereby protect her against her own will. The strong bond that women experience, then, does not convert the object of their bonding into a rights-holding entity that might limit their options. It works, instead, to provide an account of abortion choice that stems from the prospect of powerful bonding experiences (and the anticipated severing of those bonds) that women might legitimately consider in deciding whether or not to take a pregnancy to term.

${ }^{40}$ See Mammal, MERRIAM-WEBSTER DICTIONARY, http://www.merriam-webster.com/dictionary/ mammal [https://perma.cc/DW6F-D72V] (last visited Sept. 24, 2014) ("[A]ny of a class (Mammalia) of warm-blooded higher vertebrates (as placentals, marsupials, or monotremes) that nourish their young with milk secreted by mammary glands, have the skin usually more or less covered with hair, and include humans.").

${ }^{41}$ See id. (including milk secretion in the definition of mammal). See generally Anthony V. Capuco \& R. Michael Akers, The Origin and Evolution of Lactation, J. BIOLOGY (Apr. 24, 2009), www.jbiol.com/content/8/4/37 [https://perma.cc/7E5K-NU9D].

${ }^{42}$ See Carol J. Adams, The SeXual Politics of MEAT: A Feminist-Vegetarian Critical THEORY 26 (1990) ("Dietary habits proclaim class distinctions as well. Women, second-class citizens, are more likely to eat what are considered to be second-class foods in a patriarchal culture: vegetables, fruits, and grains rather than meat. The sexism in meat eating recapitulates the class distinctions with an added twist: a mythology permeates all classes that meat is a masculine food and meat eating a male activity."); see also id. at 94 ("The feminist theorist has concluded that traditional narrative is determined by patriarchal culture. According to feminist theory, patriarchal narrative depicts male quests and female passivity."); CAROL J. ADAMS, NEITHER MAN NOR BEAST: FEMINISM AND THE DEFENSE OF ANIMALS 54 (1995) ("Nonhuman animal experimentation is not an isolated case of animal oppression nor is it unrelated to human male dominance. Animal experimentation is inherent in the way men, especially privileged Euro American men, have made themselves subjects in the world by making others objects." (citation omitted)). 
then, feminists have sometimes sought to erect a wall between women and "animals" (of whom women and men are in fact one kind). People use the names of animals to insult one another, so an identification of women with animals would appear to be necessarily denigrating and disempowering. ${ }^{43}$

Yet the wall of separation between women and nonhuman animals aims to combat the subjugation of women by having women identify with the oppressor. Rather than rejecting victimization of the vulnerable generally, we instead limit ourselves to saying that we will not be victimized, and we prove this proposition by joining in the victimization of those less powerful than ourselves. This phenomenon is a familiar one, as members of one oppressed group will sometimes seek to distinguish themselves from members of another oppressed group and argue that "we" (and those who lord over us) are entitled to rights while "they" are not."

Another problem with the sharp distinction between women and other animals has to do with the facts surrounding nonhuman lives. Most people, including most women, have an imaginary vision of what it takes for a cow to produce milk "for us." I know this because my friends, colleagues, and I shared in this imaginary vision for most of our lives. As a child, my "farm animal" toy cows all had distended udders, and I assumed that cows "naturally" produced milk (which made sense to me, because the whole point of a cow was to supply humans with dairy food, so why wouldn't she naturally make milk from birth?). I had no idea that in fact, cows-like humans and other members of the mammalian class-make milk only as part of their reproductive process. ${ }^{45}$

${ }^{43}$ See Joan Dunayer, Sexist Words, Speciesist Roots, in ANIMALS AND WOMEN: FEMINIST Theoretical ExploRations 16 (Carol J. Adams \& Josephine Donovan eds., 1995) ("Likening women to nonhuman animals undermines respect for women because nonhuman animals generally receive even less respect-far less.").

${ }^{44}$ Sojourner Truth exposed the weakness in this sort of thinking in her speech, Ain't I a Woman?. See Sojourner Truth, Address at the Women's Rights Convention in Akron, Ohio (1851), http:// www.nps.gov/wori/learn/historyculture/sojourner-truth.htm [https://perma.cc/WZ8N-TN35] ("That man over there says that women need to be helped into carriages, and lifted over ditches, and to have the best place everywhere. Nobody ever helps me into carriages, or over mud-puddles, or gives me any best place! And ain't I a woman? Look at me! Look at my arm! I have ploughed and planted, and gathered into barns, and no man could head me! And ain't I a woman? I could work as much and eat as much as a man-when I could get it-and bear the lash as well! And ain't I a woman? I have borne thirteen children, and seen most all sold off to slavery, and when I cried out with my mother's grief, none but Jesus heard me! And ain't I a woman?'). She argued that the plain strength of black female enslaved persons supported some of the arguments that white women were attempting to make about their not being too "delicate" to be fit for political participation.

${ }^{45}$ See Cows Used for Dairy, Cows Used for Meat, FARM SANCTUARY, http://www.farmsanctuary. org/learn/factory-farming/dairy/ [https://perma.cc/YHE4-QUR5] (last visited Sept. 16, 2014) ("Like all mammals, dairy cows must be impregnated in order to produce milk. Cows in the dairy industry spend their lives in a constant cycle of impregnation, birth, and milking with just a few short months of rest between pregnancies."); see also Olivier Berreville, Animal Welfare Issues in the Canadian Dairy Industry, in CRITICAL ANIMAL STUDIES: THINKING THE UNTHINKABLE 195 (John Sorenson ed., 2014) ("Milk production will only increase again after another pregnancy and birth. In order to prevent the 
This truth about cows is relevant to our study here because of what it requires of dairy farmers. To "produce" milk for consumption as cheese, yogurt, ice cream, milk, etc., a dairy farmer must provide for the insemination of "his" (or "her") cows. The farmer typically achieves this impregnation by what is euphemistically called "artificial insemination" (a process that is ordinarily voluntary in humans but never voluntary in nonhuman animals). ${ }^{46}$ The device used for such insemination is sometimes referred to as a "rape rack." ${ }^{\text {"47 }}$ To make a captive cow pregnant, the farmer forcibly introduces semen into the cow's vagina. ${ }^{48}$

Plainly, the insemination process that happens to cows represents a rather extreme violation of the cows' BII. The cows do not give consent, and the process involved would arguably violate prohibitions against bestiality if the goal were sexual gratification rather than culinary gratification. But this Bodily Integrity Interest is not the reason that I bring up the plight of dairy cows.

I bring it up because of what happens to the cow after she has been pregnant and gives birth, and what that experience can teach us about women's interests. It is when a cow gives birth that she produces milk, in order to feed her newborn baby calf. Like other mammals, cow mothers are extremely attached to their newborn babies and want nothing more than to

milk supply from being interrupted for long periods of time, each cow is re-impregnated approximately two to three months after giving birth. To meet the demands for milk production, cows must thus be put through an endless cycle of insemination, pregnancy, calving, and lactation, during which they produce milk while pregnant for seven to eight months each year, only to have every one of their calves taken away at birth.").

${ }^{46}$ See generally R.H. Foote, The History of Artificial Insemination: Selected Notes and Notables, 80 J. ANIMAL SCI. 1, 3 (2002), https://www.asas.org/docs/publications/footehist.pdf [https://perma.cc/ NZ6P-ZR8G] ("Phenomenal growth of [artificial insemination] occurred in the 1940s in the United States. The procedures developed in the United States became established worldwide." (citation omitted)).

${ }^{47}$ See Gary L. Francione, InTroduction to Animal RightS: Your ChILd or the Dog? 13 (2000) ("Dairy cows are repeatedly impregnated—usually on a device called a 'rape rack,' where they are inseminated by a bull or by a human who manually inserts the bull semen-in order to keep them lactating."); see also Don't Buy the Myth!, HUMANEMYTH.ORG, http://www.humanemyth.org/downloa ds/HumaneMythHandbill.pdf [https://perma.cc/FG2G-TMH7] (last visited Sept. 17, 2014) ("All forms of dairy farming involve forcibly impregnating cows. People ... have referred to the restraining apparatus as a 'rape rack.' The process involves a person inserting his arm far into the cow's rectum in order to position her uterus, and then forcing an instrument into her vagina.").

${ }^{48}$ See Berreville, supra note 45 , at 187 ("The artificial insemination system favoured by dairy producers is recto-vaginal whereby a farm worker or veterinarian inserts his arm into the cow's rectum and, through the rectal wall, manipulates the animal's genital tract. An insemination pipette or gun is then inserted into the vagina and semen is deposited through the cervix into the uterus .... In nature, semen from a bull is released into the cow's vagina, not into her cervix. The particular invasiveness of the artificial insemination procedure is a direct consequence of the dairy industry's continuing search for increased profit: to save on cost. . . Improper handling during artificial insemination can irritate the colon; damage the urethra, bladder, cervix, or lining of the cows' uterus; and lead to infections. In dairy cows, rectal palpation and artificial insemination procedures have also been shown to increase levels of cortisol, a hormone indicative of stress." (citations omitted)). 
be able to nurse them. ${ }^{49}$ The babies feel this way too, and they find comfort, nourishment, and pleasure in nursing on their mothers. ${ }^{50}$

Within a day, however, or a few days on "humane" dairy farms, the farmer takes the baby calf away from his mother. ${ }^{51}$ If the reader is in any doubt about the emotional impact of this removal of her child on the mother cow, he or she can watch some of the many videos of the process available on the internet. ${ }^{52}$ Ordinarily a very docile being, the mother cow becomes extremely agitated, vocal, and even violent, and will often go for days without eating, pacing back and forth and returning to the spot where she last saw her baby. ${ }^{53}$

Instead of allowing her to nurse, as she so desperately wants to do, however, the farmer-serving the demand of consumers who want dairy cheese or yogurt (or other such products)_begins the "milking" process, either manually or mechanically extracting the calf's baby food for humans who neither need it nor benefit from it nutritionally. ${ }^{54}$

${ }^{49}$ See id. at 196 (discussing the dairy industry's veiling of the negative impacts that forced separation of mother and calf has on them).

${ }^{50}$ See id. at 197 ("The emotional trauma caused by separation should not be considered less severe for the calves, who are deprived of maternal care and social contact. Studies reveal that mortality rates and incidence of disease increase for calves when they are separated from their mothers. Additionally, removing calves from their mothers prevents them from fulfilling one of their most basic needs: the need for suckling.").

${ }^{51}$ The Truth Behind "Humane" Labels, FARM SANCTUARY, http://www.farmsanctuary.org/learn/ factory-farming/the-truth-behind-humane-labels [https://perma.cc/4ATA-BSSP] (last visited Sept. 24, 2014) ("Organic dairy may be free of antibiotics and [added] hormones, but it is not free of cruelty. Because cows produce milk only when pregnant or nursing, all dairy farms subject their cows to a relentless cycle of impregnation and birth. Their babies are taken away immediately, so that the milk can be collected for human use.").

${ }^{52}$ See, e.g., Michael Lanfield Raw Vegan Fruitarian, The Price of Milk, Cheese (Dairy) and Veal-Separation of a Cow and Her Calf (English), YouTUBE (Nov. 20, 2012), https://www.youtube $. \mathrm{com} / \mathrm{watch}$ ?v=SYJPbrxdn8w.

${ }^{53}$ See E.O. Price, Principles and Applications of Domestic Animal Behavior 162 (2008) ("Early weaning can be stressful to both the mother and her offspring. They are not only separated from one another but the young are prematurely and abruptly denied the opportunity to suckle. Their distress is typically expressed by an increase in activity (e.g. pacing back and forth along enclosure walls and fences), frequent vocalizations and a temporary reduction in food intake.").

${ }^{54}$ Professor T. Colin Campbell's research in nutritional biochemistry found that the dairy protein casein is associated with actuating cancer growth and is thus a carcinogenic substance. See T. COLIN CAMPBEll, \& ThOMAS M. CAMPBEll II, THE ChINA STUDY: STARTLING IMPLiCATIONS For DiET, WEIGHT LOSS AND LONG-TERM HEALTH 65 (2006) ("An impressively consistent pattern was beginning to emerge ... . [C]asein [a primary dairy protein] promotes cancer growth ...."). There is an association between dairy consumption and other chronic diseases in Western populations, relatively unheard of in places where dairy is not consumed. See, e.g., id. at 199 (discussing the association between consumption of cow's milk and autoimmune diseases). Recently, a study published in The British Medical Journal found that high consumption of dairy predicted higher mortality as well as increased fracture rates. Karl Michaellsson et al., Milk Intake and Risk of Mortality and Fractures in Women and Men: Cohort Studies, BRITISH MED. J. (Oct. 28, 2014), http://www.bmj.com/content/ 349/bmj.g6015 [https://perma.cc/5VEW-F3KZ]; see also Neal Barnard, More Milk, More Problems, PHYSICIANS COMM. FOR RESPONSIBLE MED. (Oct. 30, 2014), http://www.pcrm.org/nbBlog/index 
A cow in this situation suffers a terrible harm, and it is the harm of having a loved one ripped from her side. To highlight how devastating this harm truly is, and the extent to which cows understand the profound harm that is being done, consider the story of a large-animal veterinarian who graduated from Cornell Veterinary School. ${ }^{55}$ The veterinarian told of a farmer who called her with a mysterious situation on his hands.

One of the farmer's cows had recently given birth. When the cow returned to the barn, after giving birth on her own in the field, the farmer took her calf away, a practice that is an inherent feature of dairy farming, as explained above. Notwithstanding his taking away the calf, the cow kept returning from grazing each day without any milk in her udders. She seemed otherwise healthy, and the farmer could not figure out why she was not producing the commodity that he had bred and impregnated her to produce. The veterinarian was also perplexed.

After some investigation, the answer emerged. When the cow gave birth in the field, she had had twins. Evidently remembering that the farmer took away her babies in past birth cycles, the cow hid one of the calves and returned to the farmer with only one. Just as had occurred several times before, the farmer took her calf away.

When the cow went out to graze, though, she visited her remaining, hidden calf and nursed him with all of the milk that she had. Upon learning this, the veterinarian begged the farmer to extend mercy to the cow and permit her to keep her last calf. The farmer, however, declined to do so.

Farmers are not in the business of protecting the interest of female animals in staying with their babies. They are in the business of separating mothers and babies so that other humans-who express their demand for dairy at restaurants, farmers' markets, and grocery stores-can dine on the calves' baby food, while the calves, if male, become veal, ${ }^{56}$ or, if female,

.php/more-milk-more-problems [https://perma.cc/N3UR-TCKL] (discussing The British Medical Journal's longitudinal study as well as other evidence that dairy harms human health). Dr. Michael Greger, who has closely examined the peer-reviewed nutritional research, agrees that dairy harms human health. See Michael Greger, Dairy, NUTRITIONFACTS.ORG, http://nutritionfacts.org/topics/dairy/ [https://perma.cc/PLD4-G8ZW] (last updated Feb. 12, 2016) (providing links to articles and videos about the negative effects of dairy on human health).

55 See Article by Holly Cheever, ACTION FOR ANIMALS NEwSLETTER (Action for Animals, Seattle, WA), Issue 3, at 4, http://www.afa-online.org/newsletter3.pdf [https://perma.cc/GC3F-AFMX] (recounting the story of her experience of the bond between the mother and her calf). This experience left a strong impression on Dr. Cheever, a mother who had the luxury of being able to keep and nurse all of her babies. See id. ("All I know is this: there is a lot more going on behind those beautiful eyes than we humans have ever given them credit for, and as a mother who was able to nurse all four of my babies and did not have to suffer the agonies of losing my beloved offspring, I feel her pain.").

${ }^{56}$ Male "dairy" calves become veal, because they are not able to produce milk, but they also do not "produce" desirable meat as adults, the way that "beef" cattle do (those who are thus permitted to live a somewhat longer fraction of their ordinary lifespan). See Berreville, supra note 45, at 188-89 ("With the wide use of artificial insemination and the inability of male calves to produce milk, these animals are of no use on dairy farms and are sold [to be raised for veal]."); see also JOHN R. CAMPBELL 
are inducted into the same life of forced insemination followed by separation from their babies and, ultimately, of slaughter when her milk production slows. ${ }^{57}$

Here is a poem by Gretchen Primack that captures the violation of the dairy cow's bonds with her baby more eloquently than could any mere description:

\section{Love This ${ }^{58}$}

If you permit

this evil, what is the good

of the good of your life?

\section{-Stanley Kunitz}

The body floods with chemicals saying, Love this, and she does, and births it; it is a boy

she begins to clean and nose, but he is dragged

away by his back feet. She will never touch him

again, though she hears him howl and calls back

for days.

Her breast milk is banked for others. Her son

is pulled away to lie in his box.

He will be packed for slaughter. How ingenious

we are! To make product from byproduct.

To make use of the child,

kill and pack and truck him to plates.

And when the gallons slow, we start over, and her body says, Love this! And she does, though in a moment she will never touch him again. His milk is not for him.

et Al., ANimal Science: The Biology, Care, and Production of Domestic ANimals 35 (2002) ("As a result of bull production strategies the day-old bull calf is a surplus item on most U.S. farms. These calves are commonly sold to specialized producers who raise them for veal or slaughter beef.").

${ }^{57}$ Heifers are forced into this life at around fifteen months of age so that they are prepared to calve as two-year-olds. See HEATHER SMITH THOMAS, STOREY's GUIDE TO RAISING BEEF CATTLE 146 (3d ed. 2009); id. at 147-49 (providing advice that will help the heifer achieve the optimal weight for reproducing). Calves, both male and female, are fed a variety of milk substitutes. $I d$. at $148-49$ (listing grass, hay, grain, protein, and vitamin supplements as potential substitutes).

${ }^{58}$ Gretchen Primack, Love This, GRETCHEN PRIMACK, hittp://www.gretchenprimack.com/poetry .php?f=lovethis.txt [https://perma.cc/6SSC-7M4E] (last visited Sept. 16, 2014) (reprinted with permission from the author). 
And when the milk slows too slow, she will join him on the line, pounds of ground. And how we will dine! And talk of our glossy dogs! And her body will break up on our forks, as mothers beg us for the grain we stuffed her with, and children beg us for the water scouring her blood from the factory walls.

And when her wastes and gases and panic heat our air so hot our world stops breathing - then will we stop? Then will we grow kind, let the air cool and mothers breathe?

\section{APPLICATION OF THE DAIRY COW'S EXPERIENCE TO THE HUMAN RIGHT TO ABORTION}

My aim, in discussing the grotesque suffering to which dairy farming (and therefore dairy consumption) routinely subjects cows is to raise consciousness and also to illuminate the nature of the "INHLAA" (the Interest in Never Having Loved at All). Unlike in the case of human abortion, the coercion associated with every stage of the process in the case of a dairy cow is plain and unequivocal. The heifer (pre-gravid female cow) has no choice about being inseminated - her bodily integrity is unequivocally violated by an act that is, at the very least, analogous to rape. Then, when she gives birth and wishes to nurture and nurse her infant - a nearly universal feature of mammals-she is forcibly stopped from doing so.

For the cow, the INHLAA would be best respected by individuals rejecting dairy consumption (as I do as a vegan) so that farmers no longer have a reason to breed animals into existence for the purpose of inseminating them and then taking away their most precious new babies. Because the violence against the cow begins so early in the process, its remedy can be found at a similarly early point.

For the pregnant woman, however, the violation of her interest arises later. No one brought her into existence with the goal of turning her into a reproductive slave who provides milk to someone of another species whom she never wanted to nurse. (In our own history, however, we do find a similar practice in the breeding of human slaves, some of whom would be used as wet nurses for slaveholders' families. ${ }^{59}$ ) Because rape continues to

${ }^{59}$ See JANet Golden, A Social History of Wet NuRSING in AMERICA: From Breast to BOTTLE 25-26 (1996) ("Clearly, though, the Southem experience was differentiated by the availability 
be a serious threat to the safety and security of human women, ${ }^{60}$ for women whose pregnancies were the result of sexual assault, the argument for a right to abortion is clear to many people who are otherwise opponents. $^{61}$

The woman who becomes pregnant through consensual sex, however, experiences the beginning of coercion when she learns that she is pregnant, is unhappy about the news, and confronts laws that interfere with her ability to terminate if she wishes to do so.

As discussed, the woman may wish to have an abortion because she does not want to produce a child, either at this time, with this partner, or at all. She may also not want to remain pregnant, a physical condition that is extremely burdensome and taxing, and the likes of which we generally do not as a society impose on anyone outside of pregnancy. But a third reason might be motivating her as well.

Perhaps she is not opposed to having a child with the particular partner in question, and she does not mind being pregnant or giving birth. What she feels she cannot do is take care of a child at this time, because of her finances, the other mouths she must feed, or other circumstances that militate against her keeping the child. If so, it might seem-under these circumstances - that having her baby and giving him or her up for adoption after delivery is the ideal solution to her problem. But the INHLAA says

of slave 'mammies' and by the ideological justifications that gradually developed to support their use. Southerners accepted cross-racial wet nursing as pragmatic, just as early settlers had turned to Native American wet nurses in times of need.").

${ }^{60}$ See How Often Does Sexual Assault Occur?, RAPE, ABUSE \& INCEST NAT'L NETWORK, https://www.rainn.org/get-information/statistics/frequency-of-sexual-assault [https://perma.cc/RVC3B3XU] (last visited Sept. 30, 2015) ("According to the U.S. Department of Justice's National Crime Victimization Survey (NCVS) - there is an average of 293,066 victims (age 12 or older) of rape and sexual assault each year."); see also Violence Against Women: Fact Sheet No. 239, WORLD HEALTH ORG., http:/www.who.int/mediacentre/factsheets/fs239/en/ [https:/perma.cc/2C7N-57F2] (last updated Jan. 2016) ("Recent global prevalence figures indicate that about 1 in $3(35 \%)$ of women worldwide have experienced either physical and/or sexual intimate partner violence or non-partner sexual violence in their lifetime.").

${ }^{61}$ See ANDREW SOlOMON, FAR from the TREE: PARENTS, CHILdREN AND THE SEARCh For IDENTITY 477-536 (2012) (discussing relationships between women who became pregnant through rape, and their children). Solomon argues that women in this situation should never be forced to take their pregnancies to term. See id. at 485 ("Ready access to a safe abortion allows a woman who keeps a child conceived in rape to feel that she is making a decision rather than having the decision forced upon her. Even opponents of reproductive choice often allow for a 'rape exception.' Raped women require unfettered independence in this arena: to abort or carry to term; to keep the child or give him up for adoption."). Even many Republicans who generally oppose abortion support laws that permit abortion in the case of rape. See, e.g., Pietro S. Nivola \& David W. Brady, Red and Blue Nation?: Characteristics ANd CAUSes OF AMERICA's POlarized Politics 66 tbl. 2-2 (2006) (discussing the results of a 2004 National Election Study, where $22 \%$ of "Strong Republicans" said that abortion should be "never permitted," 37\% said that it should be permitted "[o]nly in case of rape, incest, or when the woman's life is in danger," $18 \%$ said that it should be permitted for a "clear need," and $23 \%$ said that it should be permitted "always as a personal choice"). 
otherwise. $^{62}$

\section{IMPLICATIONS FOR THE REGULATION OF ABORTION AND OTHER MATTERS}

How might an understanding of the INHLAA alter outcomes in abortion cases that come before the courts? Might women who would otherwise be unable to assert a right to abortion be able to invoke the INHLAA as an argument for protecting their reproductive freedom? And if the answer is no, then of what use is the identification of this interest to women?

Like so many questions in the law, the answer here is that "it depends." Constitutional law currently protects the abortion choice primarily as a matter of both the right to make family-related decisions and women's bodily integrity (the BII), and I do not expect that acknowledging the INHLAA would necessarily change that. In fact, the INHLAA for women who wish to avoid the bonding that happens at birth derives quite directly from the BII, so that the two interests are in that sense quite intimately linked to each other. I view the INHLAA as less a substitute for an existing doctrinal account of abortion rights than a supplement and adjunct. To that extent, I would not expect case outcomes to expressly change doctrinally because of the introduction of the INHLAA into our lexicon.

Nonetheless, the INHLAA provides an important corrective to a discourse about abortion that has become common and that has made its way into Supreme Court rhetoric: the discourse of abortion regret syndrome, embracing the notion that abortion is an act of violence to the relationship between a woman and her growing baby. ${ }^{63}$ Because pro-life

${ }^{62}$ In saying that a woman "cannot" keep her child, it is noteworthy that in most situations, it will not be the case that someone will take her child away from her when he or she is born (in the way that will literally occur when a cow gives birth to her calf), although this might be true in some cases (e.g., a woman who is in prison or has been adjudicated an unfit mother). However, women who feel unable to keep their children may experience compulsion of a less severe but nonetheless substantial sort-the type of compulsion that comes of financial limitations, a lack of emotional resilience or the capacity to care for an infant, limited access to childcare assistance from family or friends, as well as the competing needs of other family members whose life prospects and well-being would be seriously compromised by the addition of a new family member. Each of these pressures (or all of them, in combination) can create circumstances in which a woman who may be legally empowered to keep her child (because the government will not forcibly remove the child from her) feels that she really cannot keep him or her.

${ }^{63}$ See Reva B. Siegel, The Right's Reasons: Constitutional Conflict and the Spread of WomanProtective Antiabortion Argument, 57 DUKE L.J. 1641, 1641-42 (2008) (quoting the woman-protective rationale in Carhart and discussing the pervasiveness of abortion-regret talk in debates about abortion). Professor Siegel explained,

Carhart discussed an additional justification for restricting abortion-to protect women as well as the unborn: 
discussion of abortion has come to incorporate "pro-woman" rhetoric that purports to protect women from abortion, it is useful to remain cognizant of the ways in which birth followed by adoption can be precisely the sort of devastating experience from which women might be seeking to protect themselves through abortion. The INHLAA helps clarify the regrets that can accompany the failure to have an abortion. Furthermore, an understanding of how women's natural love for their newborn babies might count as a reason to support rather than a reason to oppose the practice of abortion could help judges, attorneys, and others ponder the abortion controversy in its rich complexity rather than falling prey to stereotypes about the maternal woman who keeps her baby and the unnatural loveless woman who terminates her pregnancy. Rhetoric plays an important role in shaping the ways in which doctrine develops. A corrective to the current rhetoric could, in that way, alter the law, although I cannot predict precisely how or when it might do so.

We might also examine ways in which taking account of the INHLAA has implications beyond abortion. Pregnancy and birth create one kind of intense personal connection, but so do other experiences. People become closely bonded with other people during a relationship, whether it is one of romance or platonic friendship, though the bonding tends to proceed more gradually than the intense and immediate feelings that occur in childbirth. Likewise, parents bond to their children, and children bond to their parents, even when there is no pregnancy or birth that ties parents and children together, such as in the case of adoption.

Hence, sometimes, a decision not to begin a relationship with another individual can be the product of the desire to avoid "loving and losing." For a man who decides either not to donate sperm or to resist the use of an embryo formed from his sperm by another couple, the calculation may be

Whether to have an abortion requires a difficult and painful moral decision. ... While we find no reliable data to measure the phenomenon, it seems unexceptionable to conclude some women come to regret their choice to abort the infant life they once created and sustained. See Brief for Sandra Cano et al. as Amici Curiae in No. 05-380, pp. 22-24. Severe depression and loss of esteem can follow. See $i$ bid.

... The State has an interest in ensuring so grave a choice is well informed. It is self-evident that a mother who comes to regret her choice to abort must struggle with grief more anguished and sorrow more profound when she learns, only after the event, what she once did not know: that she allowed a doctor to pierce the skull and vacuum the fast developing brain of her unborn child, a child assuming the human form.

Id. (quoting Gonzales v. Carhart, 550 U.S. 124, 159-60 (2007)). 
that "I am not ready to be a father right now, but I will feel a great sense of connection and, correspondingly, of loss if I know that my genetic offspring are somewhere out there in the world, and I am not in a position to father that offspring or have any kind of a relationship with him or her or them." Stated differently, it may be that part of what underlies the OSI-the interest in avoiding the creation of unwanted children-is the knowledge that once they exist, it will be painful to have nothing to do with them.

The INHLAA appeared to play a role in the Tennessee Supreme Court's disposition of the frozen embryo case, Davis v. Davis, ${ }^{64}$ in favor of the man opposing implantation. ${ }^{65}$ The court specifically discussed the

${ }^{64} 842$ S.W.2d 588, 603 (Tenn. 1992), reh'g granted in part, No. 34, 1992 WL 341632 (Tenn. Nov. 23, 1992). The Tennessee Supreme Court ruled in favor of the man's right not to procreate as a reason to refuse to allow the woman-who was divorced from her former husband, with whom she had created embryos - to have a frozen embryo of the former couple implanted. Id. at 604 . For a more indepth discussion of what Davis teaches us about judges' peculiar thinking about the role of pregnancy in parenthood, see Colb, supra note 31, at 118-36 (comparing the court's rationale in Davis against other cases involving fetus rights).

${ }^{65}$ The court recognized the possibility of great suffering in both a man and a woman who have a genetic child "out there" with whom they have no relationship, as part of why it is important for people to retain the right against procreation. Davis, 842 S.W.2d at 603 ("We conclude, moreover, that an interest in avoiding genetic parenthood can be significant enough to trigger the protections afforded to all other aspects of parenthood. The technological fact that someone unknown to these parties could gestate these preembryos does not alter the fact that these parties, the gamete-providers, would become parents in that event, at least in the genetic sense. The profound impact this would have on them supports their right to sole decisional authority as to whether the process of attempting to gestate these preembryos should continue."). The court observed in a footnote that "[s]perm donors may regret not having contact with their biological children, according to psychotherapist Annette Baron and psychologist Aphrodite Clamar ... . Even more so, women who have surrendered children for adoption may be haunted by concem about the child." $I d$. at $603 \mathrm{n} .28$. The court also discussed the potential financial consequences of unwanted parenthood on Junior Lewis Davis as well as the psychological pain he would experience in having children who do not live with both parents, arguably a variant on the INHLAA because it takes the child's non-existence as a superior experience, from a parent's perspective, to that of having a child in less-than-ideal circumstances (in which the genetic parents do not live with him or her). Id. at 603-04 ("Beginning with the burden imposed on Junior Davis, we note that the consequences are obvious. Any disposition which results in the gestation of the preembryos would impose unwanted parenthood on him, with all of its possible financial and psychological consequences. The impact that this unwanted parenthood would have on Junior Davis can only be understood by considering his particular circumstances, as revealed in the record. Junior Davis testified that he was the fifth youngest of six children. When he was five years old, his parents divorced, his mother had a nervous break-down, and he and three of his brothers went to live at a home for boys run by the Lutheran Church. Another brother was taken in by an aunt, and his sister stayed with their mother. From that day forward, he had monthly visits with his mother but saw his father only three more times before he died in 1976. Junior Davis testified that, as a boy, he had severe problems caused by separation from his parents. He said that it was especially hard to leave his mother after each monthly visit. He clearly feels that he has suffered because of his lack of opportunity to establish a relationship with his parents and particularly because of the absence of his father. In light of his boyhood experiences, Junior Davis is vehemently opposed to fathering a child that would not live with both parents. Regardless of whether he or Mary Sue had custody, he feels that the child's bond with the non-custodial parent would not be satisfactory. He testified very clearly that his concern was for the 
interest of the would-be father in avoiding the pain of knowing that he might have genetic children in the world with whom he has no contact or relationship. $^{66}$ As an interest that can be shared by men in some circumstances, recognition of the INHLAA might prove doctrinally attractive for those seeking equality and protection for men, not only for those looking to protect the interests of women.

In the surrogacy context as well, we might further understand that the genetic parents-those who have hired a gestational surrogate to bring a child to them - begin to have feelings and expectations about the child who will be born, such that a change of heart by the surrogate could result in heartbreak for the intending parents. In my view, this is not a sufficient reason to forcibly remove a baby from a gestational surrogate who has fallen in love with the baby to whom she has given birth, but it might mean that a surrogate should have only a relatively short period in which to change her mind or that those who hired the surrogate might retain some visitation rights in the event that the surrogate decides to keep the baby. After all, the genetic parents have implicated their INHLAA in entrusting their genetic material to a surrogate, based on the promise that the one to whom they would bond (through their expectations, preparations, and experiences such as viewing ultrasounds) would in fact become their child.

Likewise, when a woman becomes pregnant and wishes to deny the baby's father any access to the baby, the father could successfully rely on his own feelings of attachment-those that form when he learns that he has a genetic child - to argue that he is entitled to build a relationship with his child. Yet it is important to note the distinction between the relationship he wishes to build, and his own personal feelings that have developed, on the one hand, and the actual physiological relationship that the mother has already built with the baby in virtue of having borne him or her, on the other. $^{67}$

In the context of animal rights, it is not solely the cow in the dairy

psychological obstacles a child in such a situation would face, as well as the burdens it would impose on him. Likewise, he is opposed to donation because the recipient couple might divorce, leaving the child (which he definitely would consider his own) in a single-parent setting.").

${ }^{66}$ The Tennessee Supreme Court discussed how painful it would be for the father to be in a position where he knew he had a child but could not have full custody of that child or offer that child full-time access to a stable, two-parent home. See id. at 604 ("While this is not an insubstantial emotional burden, we can only conclude that Mary Sue Davis's interest in donation is not as significant as the interest Junior Davis has in avoiding parenthood. If she were allowed to donate these preembryos, he would face a lifetime of either wondering about his parental status or knowing about his parental status but having no control over it. He testified quite clearly that if these preembryos were brought to term he would fight for custody of his child or children. Donation, if a child came of it, would rob him twice-his procreational autonomy would be defeated and his relationship with his offspring would be prohibited.").

${ }^{67}$ The U.S. Supreme Court recognized the important distinction identified here in Lehr $v$. Robertson, 463 U.S. 248, 259-60 (1983). 
industry who forms powerful bonds with other animals. First, the baby calf also forms a bond to his mother, and the decision to create that baby only to take his mother away from him shortly after birth does great violence to the baby's INHLAA as well as to his mother's. In his case, moreover, his entire existence is a product of the desire to manipulate the reproductive life of his mother-he is a byproduct of that process, not even its focus. In his case, it seems clear that it would be better not to bring him into this world at all rather than to create him, a being whose overwhelming first feeling is love for his mother, only to take her away from him and soon, if he is male, to slaughter him. ${ }^{68}$

Even outside the dairy industry, farmed animals are generally highly social beings who become bonded to some of the other animals around them. Cows are known to interact with one another in a communicative fashion and to form collaborative relations and deep friendships. ${ }^{69}$ By bringing such animals into the world in order to turn them into food sources for humans, we guarantee the pain of being separated from loved ones, even for those who do not have the singular misfortune to parent infants who will be taken from them shortly after birth, as do mammals in the dairy industry.

Consider what it means to be a social being. Cows, pigs, sheep, goats, chickens, turkeys, and other animals exploited on farms (including, most commonly, in industrialized farm settings) need, as a matter of their

${ }^{68}$ For a fuller discussion of why it is not paradoxical to propose nonexistence as preferable to existence within the farmed animal world, see SHERRY F. COLB, If We All Become Vegan, Won't Farmed Animals Disappear?, in QUESTIONS PEOPLE ASK VEGANS, supra note 1, at 156-58.

The argument I address in this chapter takes various forms, each of which amounts to a claim that the animals whom we farm have actually benefitted from animal farming. If not for our consumption of domesticated animals, farmers would have no reason to bring the animals into existence, and there would eventually be no more of them. Therefore, the domesticated animals who do exist have consumers to thank for their lives, however brief and however painful.

Id. at 156.

${ }^{69}$ See, e.g., Melanie Joy, Why We Love Dogs, Eat PIGS, AND Wear Cows: AN INTRODUCTION TO CARNISM 49 (2011) ("Bovines are communicative, emotional, and social creatures. They have multiple vocalizations and gestures to communicate their feelings, and in a natural environment they will nurture ongoing friendships with one another); see also Meet the Animals: Cows, FARM SANCTUARY, http://www.farmsanctuary.org/learn/someone-not-something/1 10-2/ [https://perma .cc/RD5B-99SS] (last visited Sept. 20, 2015) ("Cows interact with one another in complex ways, forming collaborative relationships (for example, they form 'grooming partnerships,' just like chimpanzees), learning from one another, and making decisions based on altruism and compassion. Sunday Times science editor Jonathan Leake explains that "cows have a secret mental life in which they bear grudges, nurture friendships, and become excited over intellectual challenges ...' As a researcher at Moulton College in the UK, Krista McLennan has documented the fact that cattle form deep friendships and strong family bonds. Like humans, when cattle "have their preferred partner with them, their stress levels in terms of their heart rates are reduced compared with if they are with a random individual." (footnotes omitted)). 
emotional and mental well-being, to be near others. ${ }^{70}$ Isolating animals from other animals, from the accompanying stimulation of social contact, or from other means of satisfying their natural inclinations, yields mental illness that we find in farmed animals just as we do in humans who endure solitary confinement in the prison setting. ${ }^{71}$ The tremendous need that all

${ }^{70}$ See, e.g., QUESTIONS PEOPLE ASK VEGANS, supra note 1, at 18 ("When we look closely at the behavior of cows and chickens, however, we see that these creatures exhibit strong emotional attachments to other animals including - for the lucky few animals saved from farms- the humans who rescued them." (citing The Emotional World of Farm Animals, TOP DOCUMENTARY FILMS (Oct. 2004) http://topdocumentaryfilms.com/the-emotional-world-of-farm-animals/)).

${ }^{71}$ See, e.g., JOY, supra note 69, at 42-43 ("Most pigs, however-more than 100 million-spend their entire lives in intensive confinement and never see the outdoors until they are packed into trucks to be sent to slaughter. Shortly after piglets are born, they are typically castrated, and their tails are cut off, without anesthesia. Ranchers are told to remove ('dock') their tails with blunt, side-cutting pliers because the crushing action helps to reduce bleeding. Tail docking is necessary because under extreme stress and when all their natural urges have been thwarted, pigs develop neurotic behaviors and can actually bite each others' tails off. This psychological reaction is one of the symptoms of what is referred to in the industry as porcine stress syndrome (PSS), a condition that is remarkably similar to what we call in humans post-traumatic stress disorder (PTSD). Other symptoms include rigidity, panting, anxiety, blotchy skin, and sometimes sudden death. Like humans who have endured solitary confinement and other tortures in captivity, pigs have engaged in self-mutilation, and have been found repeating the same nonsensical behaviors over and over, sometimes thousands of times a day; the animals are literally driven insane. . . The technical term for repetitive behaviors is stereotypies. Stereotypies are a symptom of stress seen in a number of animal species (e.g., large cats pacing in a cage at the zoo), but they are not classified as a symptom of PSS."); see also D.M. BROOM \& K.G. JOHNSON, STRESS AND ANIMAL WELFARE 53 (1993) ("In natural conditions, animals are constantly stimulated by changes in their physical and social environments. Where animals are brought under closer environmental control, on farms, in zoos, or in people's homes as pets, the levels of some of the components of stimulation are reduced, while others are increased. . . Other animals, instead of becoming apathetic, may contrive to replace programmed requirements with stimuli of their own making, so that these appear as repetitious activities, or stereotypies. Not being responses to specific stimuli, such stereotypies can be manifest not only as purposeless routines, but as behavior which damages the animal itself or others in its vicinity. There are certain parallels in humans who experience lack of stimulation, or underload, at work. Such people can develop psychological disturbances due to failure to adapt." (citation omitted)); id. at 132-34 ("While an animal is closely confined it will be unable to carry out certain movements, and modifications in behavior will occur as a consequence. Other changes in behavior may also become evident, owing perhaps to frustration. Sows which are kept in stalls and veal calves kept in crates may have difficulty in lying down because of the cramped conditions. Normal lying movements may even be completely prevented. Some individuals respond to this by 'dog-sitting' in which the hind quarters are on the ground but the front legs are extended, a posture that is rare in more spacious conditions."); HUMANE SOC'Y OF THE U.S., AN HSUS REPORT:

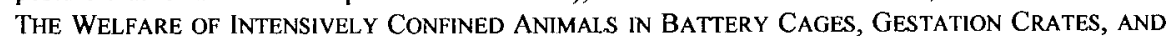
VEAL CRATES 6 (2012), http://www.humanesociety.org/assets/pdfs/farm/hsus-the-welfare-of-intens ively-confined-animals.pdf [https://perma.cc/EJU7-VSBR] ("When pigs are not confined, they are active and expressively curious animals. Scientific observation and research have found pigs to be intelligent, social animals, capable of learning complex tasks, perceiving time, and anticipating future events. When immobilized in gestation crates without environmental enrichment or mental stimulation, their psychological well-being is impaired. Pigs would naturally segregate into small groups with stable dominance hierarchies. Under free-range conditions, sows spend approximately $31 \%$ of their time grazing, $21 \%$ rooting, $14 \%$ walking, and $6 \%$ lying down. . . Intensive confinement thwarts nearly all natural behaviors, including foraging and rooting, reducing daily activity to the time it takes a sow to eat her concentrated diet. . . . When behavioral needs are denied in such highly restrictive 
social animals have for contact with others may provide some support for the principle articulated by Tennyson that it is better to have loved and lost, if the alternative to love and loss is isolation.

In providing company for animals on a farm, however, we virtually guarantee the animals the awful experience of loss at a very young age (because animals are generally slaughtered when they are either babies or adolescents). ${ }^{72}$ Animals will naturally bond with someone nearby, and having made a friend, will soon go on to lose him or her to the slaughter line. One pig farmer, Bob Comis, who claimed to be providing his "humanely raised" pigs with a good life and a painless death, acknowledged the problem of the "last pig," the overwhelming anxiety, terror, and distress of the final animal to be slaughtered, who no longer has even the comfort of the company of his fellow death row inmates. ${ }^{73}$

Comis describes the lone pig's behavior in this way:

When those bonds [among pigs, who naturally crave each other's company] are broken, a pig suffers a tremendous amount of psychological stress, most often expressed in repeated deep, long, doleful groans, and when the circumstances are right, pigs express that psychological

environments, animals may perform unnatural behaviors in place of the expression of normal patterns of activity. . . Stereotypic behaviors are more common among gestation-crated sows compared to those in group pens and include bar-biting, head-weaving, pressing their drinkers without drinking, and making chewing motions with an empty mouth (sham or vacuum chewing). The amount of time sows engage in stereotypies increases with the time spent in crates. This expression of abnormal behavior is widely accepted as a sign of psychological disturbance, frustration, and impaired welfare. By comparison, in situations where sows have greater freedom in more complex environments, the amount of stereotyped behavior is nearly zero." (citations omitted)).

${ }^{72}$ See, e.g., Hogs \& Pork: Background, U.S. DEP'T AGRIC. ECON. RESEARCH SERV., http://www.ers.usda.gov/topics/animal-products/hogs-pork/background.aspx [https://perma.cc/UPX2REV4] (last visited Dec. 24, 2014) ("In a farrow-to-finish operation, 22-26 weeks (starting at birth) are required to grow a pig to slaughter weight."); Sheep, Lamb \& Mutton: Background, U.S. DEP'T AGRIC. ECON. RESEARCH SERV., http://www.ers.usda.gov/topics/animal-products/sheep,-lamb-mutton/back ground.aspx [https://perma.cc/6ZEH-55Z5] (last visited Dec. 24, 2014) ("Most meat is sold as lamb and comes from animals under 14 months old."); Poultry \& Eggs: Statistics \& Information, U.S. DEP'T AGRIC. ECON. RESEARCH SERV., http://www.ers.usda.gov/topics/animal-products/poultry-eggs/stat istics-information.aspx [https://perma.cc/J5Q3-TYQA] (last visited Dec. 24, 2014) ("Broilers (chickens under 13 weeks old) constitute virtually all commercial chicken production."); see also QUESTIONS PEOPLE ASK VEGANS, supra note 1, at 44-45 ("Male dairy calves, sometimes called 'veal calves,' are slaughtered when they are anywhere from a few days old (when many still have an umbilical cord and attempt to suckle on the workers' fingers while being readied for slaughter) to a few months old, depending on the sort of meat desired. . . A 'broiler' chicken grows rapidly to reach full size by the age of six or seven weeks old, at which time he or she is slaughtered. People who have visited chicken slaughter facilities have reported that although the birds are large, many still utter the 'peep' sounds we associate with baby chicks, because they are in fact still babies." (citations omitted)).

${ }^{73}$ Bob Comis, What Humane Slaughterhouses Don't Solve: The Last Pig Problem, THE DoDo (Mar. 10, 2014), https:/www.thedodo.com/community/BobComis/the-last-pig-459345722.html [https: //perma.cc/AJ8J-SL8W] 
suffering (stress is an inadequate term) of broken bonds by totally and completely flipping out. They run back and forth squealing. They run aimlessly, in circles, screaming. They will jump fences, or they will plow right through them. When confined in a tight space, they will smash themselves against walls and gates, repeatedly. They will spastically chew on metal bars. They will try to climb whatever can be climbed. They will jam their snouts under the bottom rung of a gate over and over again and strain and struggle to lift it off of its hinges. They will smash themselves against the walls and gates again, repeatedly. . . . Isn't the extreme psychological suffering experienced by the last pig enough in and of itself? Shouldn't that be enough to give us pause? Shouldn't that be enough for us to question whether or not humane slaughterthe entire process, from first pig to last-is humane at all? ${ }^{74}$

In creating animals for the purpose of taking their lives, we simultaneously generate an unending road of emotional devastation, because these animals are social and gregarious beings, form powerful bonds with one another-even if those bonds do not precisely replicate that of a mother for her baby-and suffer when we decide that a friend is now "ready" to be taken away and killed. For them, the INHLAA tells us to stop consuming all manner of animal products and thereby avoid creating loves that are, by design, headed for loss after loss after loss. For this and many other reasons, it is not better for animals in the food industry to have "lived and loved and lost" their lives to slaughter than to have never lived at all. ${ }^{75}$

\section{CONCLUSION}

I have set out here to uncover and elaborate an important interest, generally overlooked, that explains why many women seek abortions and why it is important that they have the right to do so. That interest, the INHLAA, is distinct from the sorts of interests ordinarily considered in thinking about what might motivate women to choose to terminate a pregnancy, interests that focus on a desire to end or avoid an undesired association with an unwanted being. I propose here that one of the crucial reasons to protect abortion has to do with the biological inclination to bond to an infant to whom a woman has given birth.

\footnotetext{
${ }^{74}$ Id.

${ }^{75}$ For a source providing an extensive response to the argument that it is ethically acceptable or even laudable to consume animal products, because it ensures that farmed animals will not become extinct and will have the opportunity to exist, see SHERRY F. COLB, If We All Become Vegan, Won't Farmed Animals Disappear?, in QUESTIONS PEOPLE ASK VEGANS, supra note 1, at 156.
} 
In his opinion for the Court in Gonzales v. Carhart, ${ }^{76}$ Justice Kennedy invoked the strong feelings that women have for their babies as an argument against access to (a particular method of) abortion. ${ }^{77} \mathrm{He}$ suggested that women may, at least in the case of a late-term dilation-andextraction procedure, come to feel regret for having participated in killing their late-term unborn children in a particularly gruesome fashion. But in this Essay, I invoked similar maternal feelings - of love and connection with a newborn baby - to explain why women who do not intend to or cannot keep their babies, for legal, financial, or other reasons, would choose to terminate a pregnancy before the bonding begins, rather than face the torment of separation from a fully formed baby to whom they have just given birth. The interest in avoiding this pain-a pain that comes from the natural inclination to love one's newborn-is the INHLAA, and it explains why the possibility of adoption does not effectively solve the problem of many women who might want to terminate their pregnancies.

I have, in this Essay, also shared with readers the plight of female cattle (and other female mammals) in the industries that commodify nonhuman animals and the lacteal secretions of those animals, turning them into innocuous-sounding products that most of us know as dairy "milk," "cheese," "yogurt," and "butter." I have explained that demanding the creation of such products necessarily entails the imposition of tremendous suffering on cows (and sheep and goats) of the sort that many women seek to avoid by having an abortion before bonding begins. The plight of women, and that of nonhumans in the dairy industry, each has important lessons to teach us about how to approach the other.

The proper approach to the INHLAA is, of course, different for human women seeking to terminate a pregnancy and for dairy cattle who have been brought into existence to be forcibly impregnated and then robbed of their beloved calves. For women, protecting the INHLAA means allowing abortions and understanding that abortion can represent an affirmation of maternal bonding rather than a negation of it. ${ }^{78}$ For dairy cows, protecting the INHLAA means becoming vegan so that we no longer contribute to the breeding of mammalian mothers-who have the same inclinations to nurture and protect their children that humans have-who will be physically violated repeatedly but whose arguably greatest suffering will occur when they have given birth and when the farmer who supplies our

${ }^{76} 550$ U.S. 124 (2007).

${ }^{77} \mathrm{Id}$. at $159-60$.

${ }^{78}$ See Hanigsberg, supra note 15, at 398 ("Women do distinguish between children and intrauterine life, but they also distinguish between intrauterine life and mere parts of their own bodies. This distinction helps to explain why, at least for many women, abortion can be expressed as a mothering decision."); see also id. at 406 ("Part and parcel of the acknowledgment of abortion as a mothering choice is a consideration of the value of intrauterine life."). 
dairy products will claim the baby that every fiber in the cow's being tells her belongs to her. 